Jurnal Layanan Masyarakat (Journal of Public Service), vol 5 no 1 Tahun 2021, halaman 84-94

ISSN 2580-8680, e-ISSN 2722-239X

\title{
PEMBUATAN MEDIA PEMBELAJARAN BERBASIS TIK UNTUK PENGEMBANGAN E-LEARNING SISTEM BAGI GURU: STUDI PADA GURU- GURU SMP MUHAMMADIYAH 14 PACIRAN LAMONGAN
}

\section{TIK-BASED LEARNING MEDIA FOR DEVELOPING E-LEARNING SYSTEM FOR TEACHERS: STUDY ON TEACHERS OF SMP MUHAMMADIYAH 14 PACIRAN LAMONGAN}

\author{
Philipus Keban $^{1}$, Yayan Sakti Suryandaru², Nanang Haryono ${ }^{3}$ \\ ${ }^{1,3}$ Departemen Administrasi, Fakultas Ilmu Sosial dan Politik, Universitas Airlangga \\ ${ }^{2}$ Departemen Komunikasi, Fakultas Ilmu Sosial dan Politik, Universitas Airlangga \\ E-mail: nanang.haryono@fisip.unair.ac.id
}

\begin{abstract}
Learning media is an important part of the distance learning process, especially in the midst of the Covid-19 pandemic. Online learning implemented in the midst of a pandemic demands innovation. The process of learning media innovation with the use of information technology is a big part of the progress of education. E-learning as a learning model in education provides a big role and function for the world of education. E-learning as a distance learning model in the education sector provides a big function and role for the world of education, especially since the Indonesian Government since March 2, 2020 (kompas.com) is facing the Covid-19 outbreak where all students at all levels are studying at home. Teachers at all levels of education as the spearhead of the implementation of education need to be empowered by providing knowledge and skills in making innovative learning media using technology. Community service that has been carried out aims to empower teachers in making technology-based learning media. This is based on the special problems faced by teacher partners (SMP Muhammadiyah 14 Paciran), the difficulty in making innovative learning media using technology. After empowerment through lectures on the importance of e-learning, followed by training on innovative learning media with movavi, and direct assistance and use of zoom, it was concluded that (a) teacher partners of SMP Muhammadiyah 14 Pondok Pesantren Karangasem Lamongan have increased knowledge (b) Teachers are capable converting PPT into visual learning media using Movavi software, (c) The teacher is able to take pictures, edit using Movavi on a smartphone. (d) At this stage the teachers are able to make learning media starting from planning by selecting important materials, taking pictures, editing learning media, to rendering so as to produce learning media that attracts students.
\end{abstract}

Keywords: e-learning, improving the quality of learning , learning media

\begin{abstract}
abstrak
Media pembelajaran menjadi bagian penting dalam proses pembelajaran jarak jauh terlebih ditengah pandemi covid-19. Pembelajaran daring yang diimplementasi ditengah pandemi menuntut inovasi. Proses inovasi media pembelajaran dengan penggunakaan teknologi informasi bagian besar untuk kemajuan Pendidikan. E-learning sebagai model pembelajaran dalam pendidikan memberikan peran dan fungsi yang besar bagi dunia pendidikan. E-learning sebagai model pembelajaran jarak jauh sektor pendidikan memberikan fungsi dan peran yang besar bagi dunia pendidikan lebih-lebih saat ini Pemerintah Indonesia sejak 2 Maret 2020 (kompas.com) menghadapi wabah covid-19 dimana semua siswa pada semua jenjang belajar
\end{abstract}


dirumah. Guru pada semua jenjang pendidikan sebagai ujung tombak pada pelaksanaan Pendidikan perlu diberdayakan dengan memberi bekal pengetahuan, ketrampilan dalam membeuat media pembelajaran yang inovatif dengan pemanfaatan teknologi. Pengabdian masyarakat yang telah dilaksankaan bertujuan untuk pemberdayaan guru dalam membuat media pembelajaran berbasis teknologi. Hal tersebut didasari permasalahan khusus yang dihadapi mitra guru (SMP Muhammadiyah 14 Paciran) kesulitan dalam pembuatan media pembelajaran inovatif dengan penggunaan teknologi. Setelah dilaksankaan pemberdayaan melalui ceramah pentingnya pembelajaran e-learning, dilanjutkan dengan pelatihan inovasi pembaatan media pembelajaran dengan movavi, dan pendampingan baik melalui langsung dan penggunaan zoom disimpulkan (a) mitra guru SMP Muhammadiyah 14 Pondok Pesantren Karangasem Lamongan telah bertambah pengetahuannya (b) Guru mampu mengubah PPT menjadi media pembelajaran visual dengan menggunakan software movavi, (c) Guru mampu untuk pengambilan gambar, editing menggunakan movavi pada smartphone. (d) Pada tahap ini guru-guru mampu membuat media pembelajaran mulai dari perencanaan dengan memilih materi penting, pengambilan gambar, melaksanakan editing media pembelajaran, sampai rendering sehingga menghasilkan media pembelajaran menarik siswa.

Kata kunci: e-learning, media pembelajaran, peningkatan mutu pembelajaran

\section{PENDAHULUAN}

Perangkat digital dengan kemajuan teknologi saat ini banyak digunakan untuk pembuatan media pembelajaran. Platform media pembelajaran uang diunggah menggunakan pada jaringan internet memudahkan akses dari dimanapun dan kapanpun terlebih ditengah pandemi covid-19 dengan diterapkannya kebijakan belajar dari rumah (BDR) oleh Menteri Pendidikan dan Kebudayaan (Mendikbud) Nadiem Anwar Makarim sejak 16 Maret 2020 sampai Desember 2020.

Sistem pendidikan tradisional tatap muka merupakan cara belajar yang dinilai sangat baik bagi banyak orang. Interaksi langsung, bertemu fisik membuat atmosfir pembelajaran lebih mendukung dalam transfer informasi dan transfer keahlian dari guru ke siswa. Namun ditengah pandemi proses tersebut tidak dapat dilaksanakan sebagai upaya menekan penyebaran covid-19 pada siswa. Guru dan sekolah didorong menerapkan media baru dalam proses belajar mengajar.

Pada pelaksanaan BDR guru didorong menghasilkan bahan ajar, media ajar dan melaksanakan pembelajaran yang memberi informasi akademis dan kondisi menyenangkan bagi peserta didik. Berkaitan dengan pengembangan media pembelajaran, teknologi yang ada dapat digunakan untuk tujuan memodifikasi konten, membuat konten, dan berbagi informasi melalui penggunaan perangkat digital dengan jaringan internet.

Dunia pendidikan telah mencapai tingkat di mana berbagai bagian, orang, platform internet, dan perangkat terhubung smartphone untuk infrastruktur pembelajaran yang produktif. Pelajar sekarang memiliki peran utama dalam proses pembelajaran. Belajar mandiri dengan panduan guru melalui media internet. Konten dalam media pembelajaran sangat penting dalam pendidikan, dan pembuat kebijakan pendidikan Indonesia menyadari pentingnya media pembelajaran yang menarik dan menyenangkan. Pengaruh penggunaan media pembelajaran dengan platform internet tidak dapat diremehkan meskipun penggunaan dan keluaran media masih sedikit dijalankan. Komunikasi digital terlebih ditengah pandemi covid-19 penting untuk berjalannya proses belajar anak didik.

Sistem komunikasi media internet saat ini sedang membuat gelombang melalui pengenalan cara-cara belajar baru dalam belajar. Kemampuannya untuk memastikan 
ketersediaan konten di mana saja tanpa terhambat ruang dan waktu fisik membuatnya lebih bermanfaat dalam pembelajaran di Indonesia.

Di Indonesia pada masa pandemi, karena penerapan kebijakan BDR terdapat indikasi bahwa penggunaan media internet untuk Pendidikan berkembang pesat di kalangan siswa yang secara informal menggunakan perangkat digital berbeda di rumah untuk mengakses platform sosial. Penggunaan media pembelajaran berbasis teknologi bagian dari berkembangnya penggunaan komputer dan smartphone untuk mengakses data yang dibutuhkan baik oleh siswa dan guru. Hal tersebut dilakukan terutama melalui YouTube, Blog, Podcast, Facebook, Twitter, dan lain sebagainya. Penggunaan teknologi dibidang Pendidikan telah memperkenalkan kecepatan, kreativitas, kualitas, kolaborasi, dan kesenangan dalam pembelajaran. Kemunculan media telah mendobrak batasan-batasan yang terkait dengan sistem pembelajaran formal tradisional yang membuat para guru hanya bertanggung jawab atas urusan belajar dan siswa secara pasif dalam kungkungan ruang kelas. Media baru dapat dilihat sebagai sarana untuk memperkenalkan sektor pendidikan yang berkualitas terutama di bidang yang memungkinkan siswa dan guru memiliki akses ke konten di mana pun mereka berada jika perangkat digital yang terhubung ke Internet tersedia. Akses tak terbatas ke konten dengan ketentuan membuat dan berbagi konten semacam itu dapat meningkatkan ketersediaan pendidikan yang berkualitas.

Rosenberg menyampaikan Pengembangan e-learning dalam penyampaian pembelajaran berlandaskan tiga kriteria yaitu: (1) e-learning merupakan sistem mampu menyimpan, mendistribusi dan membagi materi ajar atau informasi, (2) pengiriman sampai ke pengguna dengan komputer melalui teknologi internet (3) e-learning merupakan jaringan luas dibanding paradigma pembelajaran tradisional (Rosenberg $2001 ; 28)$.

Pada program pengabdian masyarakat ini, dengan bermitra dengan SMP Muhammadiyah 14 Paciran (Pondok Pesantren Karangasem) Lamongan Jatim menyusun program pelatihan dan pendampingan pengembangan e-learning system bagi guru untuk meningkatkan mutu pembelajaran.

Persoalan mitra keterbatasan sumber daya manusia, sarana prasarana dan sumber belajar dalam melaksanakan BDR. Guru dan sekolah didorong memanfaatkan teknologi dalam proses pembelajaran.

Melaksanakan BDR sekolah dan guru perlu melakukan identifikasi kebutuhan, penyiapan kebutuhan yang diperlukan, perancangan model pembelajaran serta pengembangannya terutama dalam pengembangan e-learning. Sebelum diskusi lebih jauh perlu dipaprkan definisi e-learning.

(Farhad, 2001) merujuk glossary of e-learning terms menyatakan bahwa $e$ learning adalah alat penunjang dalam sistem pendidikan menggunakan media internet, jaringan komputer dan computer, serta smartphone untuk mendukung belajar mengajar. Berikut model peningkatan mutu pendidikan melalui e-learning: 


\begin{tabular}{|c|c|c|}
\hline Input Pendidikan & Proses pendidikan & $\begin{array}{c}\text { Output } \\
\text { pendidikan }\end{array}$ \\
\hline \multirow{6}{*}{$\begin{array}{l}\text { 1. Informasi } \\
\text { 2. Energi dan } \\
\text { Tenaga } \\
\text { 3. Bahan-bahan }\end{array}$} & Faktor-faktor & \multirow{6}{*}{$\begin{array}{l}\text { Orang-orang } \\
\text { terdidik } \\
\text { berbasis } \\
\text { teknologi } \\
\text { informasi }\end{array}$} \\
\hline & $\begin{array}{c}\text { Kebijakan (mencakup sistem pembiyaan } \\
\text { dan arah pengembangan) }\end{array}$ & \\
\hline & $\begin{array}{c}\text { isi atau materi(kurikulum harus berbasis } \\
\text { teknologi informasi dan komunikasi) }\end{array}$ & \\
\hline & SDM(tenaga pengajar) & \\
\hline & $\begin{array}{l}\text { Penyediaan perangkat kerasnya (sarana } \\
\text { dan prasarana) }\end{array}$ & \\
\hline & Sumber Dana & \\
\hline
\end{tabular}

Gambar 1. Model Pengembangan E-learning

Sumber: (Lovi Triono, 2007 dalam http://directory.umm.ac.id/tik/e-learning.pdf)

Berdasarkan model diatas e-learning pendidikan memiliki lima proses pembelajaran yaitu: (1) media pembelajaran dari ruang kelas ke di mana dan kapan saja, (2) pembuatan media dari pelatihan ke penampilan, (3) fasilitas dari fisik tatap muka kelas beralih ke fasilitas jaringan kerja, (4) sebelumnya menggunakan kertas beralih ke "on line" (5) sebelumnya terjadwal khusui waktu siklus ke waktu luas, Rosenberg (2001).

Permasalahan khusus yang dihadapi mitra (SMP Muhammadiyah 14 Paciran) adalah perlunya pengembangan media pembelajaran berbasis TIK untuk pengembangan elearning dan peningkatan SDM guru. Pemikiran ini berangkat dari dorongan pelaksanaan pembelajaran daring dimasa pndemi covid-19 sehingga pembelajaran tatap muka perlu didorong ke pemanfaatan ICT. Berdasarkan persoalan yang berhasil diidentifikasi diatas selanjutnya ditelaah untuk dicari solusi penyelesaian. Pendekatan yang digunakan adalah pelatihan dan pendampingan pengembangan e-learning system bagi guru SMP Muhammadiyah 14 Paciran (Pondok Pesantren Karangasem) Lamongan Jatim untuk meningkatkan mutu pembelajaran.

Berdasarkan identifikasi persoalan mitra yang telah diidentifikasi diatas dengan sebagai upaya meningkatkan mutu pembelajaran dalam mewujudkan konsep sekolah berbasis teknologi informasi dan komputer diajukan solusi sebagai berikut:

Tabel 1 Solusi Permasalahan Khusus yang dihadapi Mitra

\begin{tabular}{cll}
\hline No & \multicolumn{1}{c}{ Permasalahan Mitra } & \multicolumn{1}{c}{ Metode Penyelesaian Persoalan } \\
\hline 1 & $\begin{array}{l}\text { Persoalan mewujudkan } \\
\text { pembelajaran berbasis teknologi } \\
\text { informasi dan komputer }\end{array}$ & $\begin{array}{l}\text { Alih teknologi pembuatan media } \\
\text { pembelajan berbasis TIK movavi untuk } \\
\text { pengembangan e-learning }\end{array}$ \\
\hline 2 & $\begin{array}{l}\text { Kesulitan mencari fasilitator untuk } \\
\text { mewujudkan pembelajaran berbasis } \\
\text { teknologi informasi dan komputer }\end{array}$ & $\begin{array}{l}\text { Pelatihan pembuatan media pembelajan } \\
\text { berbasis TIK movavi sebagai media } \\
\text { pembelajaran untuk materi, penugasan, } \\
\text { petunjuk penggalian materi }\end{array}$ \\
\hline 3 & $\begin{array}{l}\text { Kesulitan mencari pendampingan e- } \\
\text { learning untuk guru }\end{array}$ & $\begin{array}{l}\text { Pendampingan operasional pengembangan } \\
\text { e-learning materi, penugasan, petunjuk } \\
\text { penggalian materi }\end{array}$ \\
\hline
\end{tabular}

Sumber data: primer, 2020 
Paradigma sistem pendidikan tradisional dengan tatap muka, beralih menjadi sistem pendidikan daring yang tidak dibatasi oleh ruang dan waktu dengan penggunaan teknologi internet. Pada konsep e-learning huruf e pada berarti elektronik. Berdasarkan konsep tersebut berkembang virtual learning (pembelajaran di dunia maya). Jadi $e$ learning berarti pembelajaran dengan menggunakan media internet menggunakan audio, video, perangkat komputer, atau kombinasi dari ketiganya. Bates dan Wulf (1996) mengemukakan kelebihan e-learning sebagai berikut: 1). Meningkatkan interaksi gusu dan siswa dalam proses pembelajaran (enhance interactivity); 2). Mempermudah interaksi guru dan siswa melalui media internet dalam pembelajaran dari mana dan kapan saja (time and place flexibility); 3). jangkauan yang lebih luas (potential to reach a global audience); 4). Mempermudah penyimpanan media pembelajaran untuk dapat diakses diaman saja (easy updating of contents as well as archivable capabilities).

E-learning sejalan dengan perkembangan kognitif dalam pembelajaran. Fisher (2005, 12) mengamati bahwa Piaget menggunakan penalaran logis sebagai faktor sentral kecerdasan. Dia menganggap perkembangan kecerdasan logis terjadi dalam tahap-tahap kunci tertentu melalui operasi anak di dunia. Pengamatan Fisher (2005) memberi karya Sampath, Panneerselvam, dan Santhanam (2006) sebuah landasan dan mereka menjelaskan bahwa ada ledakan pengetahuan, dan siswa memiliki sedikit kesempatan untuk mengeksplorasi kurikulum secara mendalam. Mereka menyarankan bahwa untuk mengatasi tantangan tersebut, guru perlu menggunakan perangkat komunikasi yang baru dan lebih baik di kelas.

Posisi Piaget tentang nature and nurture tidak dapat diabaikan dalam perkembangan kognitif anak-anak. Lightfoot, Cole, dan Cole $(2013,19)$ menyatakan bahwa "alam mengacu pada motivasi bawaan anak-anak untuk belajar dan mengeksplorasi, serta pematangan otak dan tubuh mereka. Pengasuhan mengacu pada semua pengalaman yang dipelajari anak-anak. Sebagaimana susunan biologis anak berkontribusi pada perkembangan kognitif, dampak dari bantuan dan dukungan yang tepat juga penting.

Faktor stimulus media baru tidak membatasi media. Aksesibilitas media dimanapun juga dapat menempatkannya sebagai stimulus vital. Fisher $(2005,31)$ menyampaikan bahwa "pemikiran kreatif tidak terjadi dalam ruang hampa: ia membutuhkan beberapa stimulus, beberapa konten untuk dikerjakan". Media pembelajaran dengan teknologi memiliki konten yang merangsang yang dapat mendorong perkembangan kognitif peserta didik. Dalam memperkuat karya Fisher (2005), Renzuilli dan Reiz (2009, 67) mengamati bahwa "informasi tindakan tumbuh dari apa yang menarik perhatian seorang anak, menarik perhatiannya. Percikan itu dapat terjadi ketika dia dipengaruhi oleh seseorang, sebuah ide, sepotong informasi atau suatu area aktivitas atau pekerjaan ". Media pembelajran dapat memicu percikan dalam proses pembelajaran, tetapi perilaku pengguna dapat memicu percikan tersebut menjadi positif atau negatif. Positif atau negatifnya media baru dapat dinilai melalui "nature and nurture".

E-learning memberi keuntungan dan 365 hari sepanjang tahun dibandingkan dengan pembelajaran kelas tatap muka yang harus dijadwalkan. E-learning bagi pelajar tidak potensi konflik penjadwalan. Secara ekonomi, elearning hemat biaya karena konten kursus setelah dikembangkan dapat dengan mudah dimodifikasi di masa depan, digunakan untuk pengajaran dan pelatihan. Kelemahan elearning sangat bergantung jaringan internet, kuota, dan perangkat keras computer dan smartphone. 
Keuntungan tatap muka dibandingkan E-learning adalah kehadiran instruktur secara fisik di ruang kelas, yang dapat menyelesaikan pertanyaan siswa secara langsung sehingga atmosfir pembelajaran terbangun dengan baik. Elearning memberikan siswa untuk belajar dengan kecepatan mereka sendiri, tetapi relasi guru dan siswa didorong melalui kursus dalam kerangka waktu tertentu. Dalam E-learning siswa dapat mempelajari apa yang penting dan dapat melewatkan informasi yang tidak perlu, tetapi dalam pembalajaran tatap muka semua siswa diajarkan semua informasi dan pada tingkat yang sama dengan kelas lainnya. Setelah mempertimbangkan semua faktor ini, dapat dikatakan bahwa e-learning penting untuk menunjang pembelajaran tatapo muka. Konsep ini sering juga diistilahkan dengan blended learning yaitu perpaduan antara pembelajaran konvensional di dalam kelas (tatap muka guru dan siswa) dengan pembelajaran e-learning berbasis web (online).

\section{METODE PENGABDIAN MASYARAKAT}

Alih teknologi Pengembangan e-learning dengan pengembangan media pembelajaran menggunakan TIK movavi. Pengembangan media pembelajaran difasilitasi pelaksana pengmas Dosen Fisip Unair Untuk selanjutnya Metode pendekatan yang ditawarkan untuk penyelesaian persoalan mitra yaitu dengan metode Participatory Rural Appraisal (PRA) dengan melibatkan partisipasi mitra lebih banyak yang terdiri dari semua stakeholders dengan difasilitasi oleh pelaksana pengmas dosen Fisip unair yang lebih berfungsi sebagai narasumber atau fasilitator. Metode pelaksanaan pada program Pengabdian Masyarakat Universitas Airlangga ini adalah

\begin{tabular}{|c|c|}
\hline Metode pelaksanaan & Penjelasan \\
\hline Survai pra-pelatihan & $\begin{array}{l}\text { Tim memberikan sejumlah pertanyaan } \\
\text { untuk mengetahui tingkat kemampuan } \\
\text { guru-guru dalam membuat media } \\
\text { pembelajaran untuk pengembangan }\end{array}$ \\
\hline \multirow[t]{3}{*}{ Ceramah } & $\begin{array}{l}\text { Ceramah pemateri } \\
\text { pembelajaran e-learning. }\end{array}$ \\
\hline & $\begin{array}{l}\text { Pemateri pengembangan media } \\
\text { pembelajaran berbasis TIK }\end{array}$ \\
\hline & $\begin{array}{l}\text { Ceramah pembuatan media } \\
\text { pembelajaran berbasis TIK dengan } \\
\text { movavi mulai pra-produksi, produksi } \\
\text { dan pasca produksi }\end{array}$ \\
\hline $\begin{array}{l}\text { Pelatihan dan praktik membuat media } \\
\text { pembelajaran }\end{array}$ & $\begin{array}{l}\text { Praktik perencanaan dengan memilih } \\
\text { materi, membuat story board, } \\
\text { mengembil gambar film, editing, dan } \\
\text { render film media pembelajaran }\end{array}$ \\
\hline Pendampingan dengan komunikasi & Bertujuan untuk memberikan \\
\hline $\begin{array}{l}\text { Grup Whatsapp dan apabila } \\
\text { dibutuhkan tatap muka dengan } \\
\text { menggunakan zoom atau google meet }\end{array}$ & $\begin{array}{l}\text { pendampingan secara langsung apabila } \\
\text { terdapat persoalan dalam } \\
\text { pengembangan media pembelajaran. }\end{array}$ \\
\hline
\end{tabular}




\section{HASIL DAN PEMBAHASAN}

Kegiatan pengabdian masyarakat yang dilaksanakan telah dilaksanakan sesuai perencaaan dan berjalan dengan lancar. Kegiatan dimulai dengan melakukan komunikasi dan dating ke lokasi mitra untuk tahap penyusunan rencana kerja. Kegiatan diskusi dan brain stroming dengan mitra dilakukan guna untuk mengidentifikasi permasalahan yang ada di SMP Muhammadiyah 14 Pondok Pesantren Karangasem Lamongan yang selanjutnya dicarikan pemecahan persoalan mitra dengan kegiatan pengabdian masyarakat. Kegiatan survey tersebut menghasilkan kesepakatan hasil diskusi dengan Kepala Sekolah SMP Muhammadiyah 14 Pondok Pesantren Karangasem Lamongan untuk mengembangkan pembelajaran berbasis TIK pada GuruGuru SMP Muhammadiyah 14 Pondok Pesantren Karangasem Lamongan melalui pengembangan media pembelajaran berbasis teknologi.

Pelaksanaan Kegiatan:

Pelaksana kegiatan pengabdian masyarakat berjudul "Pelatihan dan Pendampingan Pengembangan E-Learning System bagi Guru SMP Muhammadiyah 14 Lamongan Jatim Untuk Meningkatkan Mutu Pembelajaran yaitu:

\begin{tabular}{llcc}
\hline \multicolumn{1}{c}{ Nama } & \multicolumn{3}{c}{ Tugas } \\
\hline Philipus Keban, S.IP.,M.Si. & $\begin{array}{l}\text { Pemateri pentingnya pembelajaran } \\
\text { elearning }\end{array}$ & media \\
\hline Nanang Haryono, S.IP.,M.Si. & $\begin{array}{l}\text { Pemateri } \\
\text { pembelajaran berbasis TIK }\end{array}$ & pengembangan \\
\hline Aphief Tri Artanto, ST, M.Sn. & $\begin{array}{l}\text { Pemateri pembuatan media ajar } \\
\text { berbasis TIK dengan movavi }\end{array}$ & \\
\hline Tim Mahasiswa & $\begin{array}{l}\text { Supporting kegiatan untuk menyiapkan } \\
\text { tempat, absensi, dokumentasi kegiatan }\end{array}$ \\
\hline
\end{tabular}

Sasaran

Sasaran kegiatan pengmas adalah guru-guru SMP Muhammadiyah 14 Pondok Pesantren Karangasem Lamongan. Karena kondisinya ditengah pandemi hasil dari diskusi dengan Kepala Sekolah disepakati guru-guru yang dilatih berjumlah 5 guru karena memperhatikan protokol kesehatan disaat pandemi covid-19.

Lokasi dan Jadwal Pelaksanaan

Lokasi dan jadwal pelaksanaan pengmas:

\begin{tabular}{ll}
\hline Lokasi & Pelaksanaan Pengmas \\
\hline Lab computer SMP Muhammadiyah & Pelaksanaan tatap muka pada Rabu \\
14 Pondok Pesantren Karangasem & tanggal 30 September 2020 \\
Lamongan &
\end{tabular}

Pelaksanaan daring terus berlanjut dengan menggunakan media WA grup

Jadwal pelaksanaan ada tatap muka langung dan ada yang mengunakan media sosial Grup Whatsapp. Tujuannya apabila ada persoalan dalam pengembanagan media pembelajaran dapat ditanyakan langsung dengan tim pelaksana pengmas Fisip Universitas Airlangga. Grup ini direncanakan aktif sampai dengan akhir masa pengabdian masyarakat TA 2020. Tidak menutup kemungkinan akan 
berlanjut sampai dengan para guru yang dilatih dan didampingi dapat membuat media pembelajaran berbasis TIK.Dokumentasi pelaksanaan kegiatan pengmas sebagai berikut:

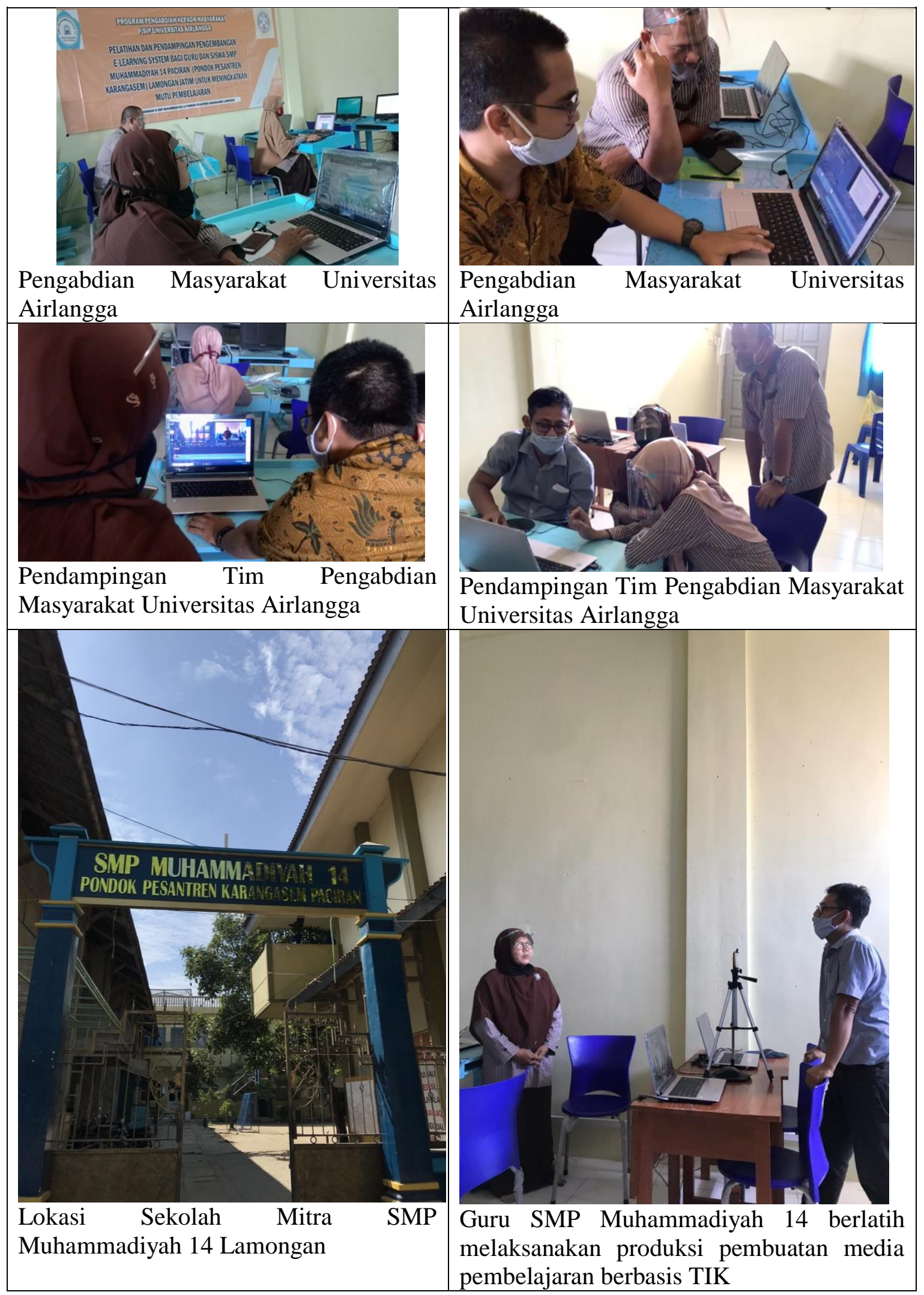


Gambar 3. Dokumentasi pelaksanaan pengabdian

Sumber: Tim Pengabdian 2020

Hasil kegiatan adalah guru-guru mampu membuat media pembelajaran berbasis TIK dengan menggunakan software movavi. Sedangkan Output yang didapat dari kegiatan pengabdian masyarakat ini diantaranya adalah: Guru-Guru SMP Muhammadiyah 14 Pondok Pesantren Karangasem Lamongan memiliki pengetahuan pembelajaran berbasis TIK yang dapat dijalankan ditengah Pandemi Covid-19. Guru-Guru SMP Muhammadiyah 14 Pondok Pesantren Karangasem Lamongan mampu membuat perencanaan, produksi dan pasca produksi media pembelajaran berbasis TIK dengan software movavi.

Outcome kegiatan pengmas yang diharapkan: Guru-Guru SMP Muhammadiyah 14 Pondok Pesantren Karangasem Lamongan mampu mengembangkan media pembelajaran berbasis TIK secara mandiri. Guru-Guru SMP Muhammadiyah 14 Pondok Pesantren Karangasem Lamongan mampu membuat media pembelajaran berbasis TIK sehingga pembelajaran menjadi lebih menarik dan mampu meningkatkan capaian pembelajaran setiap mata ajaran.

\section{KESIMPULAN DAN SARAN}

Setelah dilaksanakaan program pengabdian masyarakat dapat disimpulkan (a) guruguru SMP Muhammadiyah 14 Pondok Pesantren Karangasem Lamongan yang dilatih mendesain dan menerapkan pembelajaran berbasis TIK telah bertambah pengetahuannya (b) Guru mampu mengubah PPT menjadi media pembelajaran visual dengan menggunakan software movavi, (c) Guru-guru yang dilatih membuat media pembelajaran film juga telah mampu membuat dengan menggunakan perlengkapan yang dimiliki diantaranya smartphone untuk pengambilan gambar, editing menggunakan movavi. (d) Pada tahap ini guru-guru mampu membuat media pembelajaran mulai dari perencanaan dengan memilih materi penting pelajaran yang disampaikan, membuat story board, pengambilan gambar (film), melaksanakan editing film, sampai rendering sehingga menghasilkan media pembelajaran menarik siswa melalui proses inovatif berbasis teknologi. Disarankan kepada Kepala Sekolah SMP Muhammadiyah 14 mengembangkan pembuatan media pembelajaran oleh guru lainnya dengan berbasis TIK di SMP Muhammadiyah 14 Pondok Pesantren Karangasem Lamongan. Untuk sekolah-sekolah lain disarankan untuk mengembangkan pembelajaran berbasis TIK pada guru-guru di tengah pandemi covid-19.

\section{DAFTAR PUSTAKA}

Alan, Jonathan Ritter \& David Stavens. (2001) .The Online Learning Handbook. Developing and Using web-Based Learning".New York : Stylus Pulishing inc.

Ali. M. dkk. (2006) .Pengembangan E-Learning Jurusan Pendidikan Teknik Elektro FT UNY. Laporan Penelitian Research Grant PHK A2 Diknik Elektro FT UNY. Yogyakarta 
Ali, M. Istanto. Yatmono. Munir. (2008) .Studi Pemanfaatan E-Learning Sebagai Media Pembelajaran Bagi Guru SMA dan SMK Daerah Istimewa Yogyakarta. Laporan Penelitian Pusat Studi Pendidikan dan Teknologi Kejuruan (Pusdi PTK) Uinersitas Negeri Yogyakarta. Yogyakarta

Chu, Alan G; Thompson. Melody M; Hancock. Burton W. (998). .The Mc Graw- Hill Handbook of Distance Learning.. New York : McGraw-Hill

Eileen, T. Bender. (2001) : Introduction to Distance Learning. http://www.indiana.edu/ scs/dl prime.html. diambil pada mei 2006

Farhad S. (2001). Distance Education : An Introduction . Saba \& Associates. http://www.distance-educa-tor.com/portals/research_deintro.html diambil pada mei 2004.

Fisher, R. (2005). Teaching children to think (2nd ed.). Cheltenham, UK: Nelson Thornes

Int. (1996) Chapter 1 : Introduction to Distance Learning; http://www.indiana.edu/ scs/dl prime.html.

Lightfoot, C., Cole, M., \& Cole, S. (2013). The development of children (7th ed.). New York, NY: Worth.

Mohandas. R. (2003). ICT and e-learning in Indonesia. Presentasi di Taiwan. Taiwan. 25-27 Maret.

Munir Dr .(2007). Strategi Pengembangan B2b E-Commerce. Bahan Kuliah pada Prodi Pendidikan Ilmu Komputer UPI Bandung .Universitas Pendidikan Indonesia. Bandung. 12 November.

Renzuilli, J., \& Reiz, S. (2009). Light up your child's mind (1st ed.). New York, NY: Little Brown

Sampath, K., Panneerselvam, A., \& Santhanam, S. (2006). Introduction to educational technology (5th ed.). New Delhi, India: Sterling Publishers

Soekartawi .(2003). E-Learning di Indonesia dan Prospeknya di Masa Mendatang. Presentasi pada Seminar e-Learning perlu e-Library. Universitas Petra. Surabaya. 3 Februari.

Sidik,Ahmad.Ridwan .(2007). Etika Komputer Dan Tanggung Jawab Professional di Bidang Teknologi Informasi. SMA Islam Nuruk Karomah. 6 September

Surjono. H. (2007). Pengantar e-learning dan implementasinya di UNY. http://elearning.uny.ac.id

Sri Anindiati Nursastri.(2020).Bulan Ini, Indonesia Masuki Fase Kritis Corona. https://www.kompas.com/sains/read/2020/04/02/090300323/bulan-ini-indonesiamasuki-fase-kritis-corona. Akses 4 April 2020 
Philipus Keban, dkk: Pembuatan Media Pembelajaran Berbasis TIK Untuk Pengembangan Elearning Sistem Bagi Guru : Studi Pada Guru-Guru SMP Muhammadiyah 14 Paciran Lamongan

Wahid, Fathul. (2003). Peran Teknologi Informasi Dalam Modrenisasi Pendidikan. Universitas Islam Indonesia. Yogyakarta. 3 Juli. 